Konrad Pawtowski

\title{
Kosowo - od interwencji militarnej do deklaracji niepodległości
}

Ogłoszenie niepodległości przez Kosowo spotkało się ze sprzecznymi reakcjami ze strony społeczności międzynarodowej, stało się także powodem niesłabnącej dyskusji w nauce o stosunkach międzynarodowych. Z pewnością decyzję władz w Prisztinie można postrzegać w rożny sposób i widzieć w niej realizacje prawa narodów do samostanowienia, dokończenie procesu rozpadu wielonarodowej Jugosławii, zakończenie kolejnej fazy serbsko-albańskiego sporu o terytorium Kosowa, bezpośredni skutek interwencji militarnej NATO, wynik geopolitycznej rywalizacji mocarstw, wreszcie myśleć o niepodległości Kosowa jako o historycznym błędzie i wielkiej pomyłce Zachodu. Pomijając w tym miejscu kwestię trafności powyższych ocen oraz problem obecnego statusu Kosowa, który w dalszym ciagu budzi spore kontrowersje, konieczne wydaje się prześledzenie procesu, jaki w bezpośredni sposób doprowadził do ogłoszenia niepodległości przez południową prowincję Serbii.

\section{Interwencja militarna NATO i administracja ONZ w Kosowie}

Jakkolwiek przesłanki i podstawy prawne interwencji militarnej NATO przeciw Jugosławii były szeroko dyskutowane i niejednokrotnie kwestionowane, słuszne wydaje się 
stwierdzenie, że zasadniczą przyczynę międzynarodowego zaangażowania w Kosowie stanowił konflikt serbsko-albański, który w latach 1998-1999 przybrał formę otwartej konfrontacji militarnej. Kiedy podejmowane przez społeczność międzynarodową działania dyplomatyczne, mające na celu powstrzymanie walk w Kosowie i towarzyszacego im kryzysu humanitarnego, związanego z falami albańskich uchodźców, okazały się nieskuteczne, NATO zdecydowało się wymusić zakończenie konfliktu zbrojnego za pomoca interwencji militarnej, tj. operacji powietrznej „Allied Force” przeciw Federacyjnej Republice Jugosławii (SRJ) ${ }^{1}$.

Interwencja ta została zakończona $\mathrm{w}$ wyniku przyjęcia przez Jugosławię planu pokojowego opracowanego przez Zachód i Rosję, który zyskał autoryzację Organizacji Narodów Zjednoczonych (ONZ). W dniu 10 czerwca 1999 r. Rada Bezpieczeństwa ONZ przyjęła rezolucję nr 1244, która zobowiązywała SRJ do wycofania z Kosowa wszystkich jednostek armii i policji oraz sankcjonowała wejście do prowincji międzynarodowych sił wojskowych (Kosovo Force, KFOR) pod kierownictwem NATO. Rezolucja przywracała autonomiczny status Kosowa i ustanawiała wyłączną cywilną administrację ONZ nad prowincją przy jednoczesnym, formalnym potwierdzeniu terytorialnej integralności Jugosławii. W rezultacie Kosowo pozostawało de iure częścią SRJ, która przejściowo znalazła się pod zarządem $\mathrm{ONZ}^{2}$.

$\mathrm{W}$ celu realizacji postanowień rezolucji nr 1244 została utworzona Misja Tymczasowej Administracji Organizacji

${ }^{1}$ N. Malcolm, The War over Kosovo, [w:] War and Change in the Balkans. Nationalism, Conflict and Cooperation, ed. by B.K. Blitz, Cambridge 2006, s. 143-155.

${ }^{2}$ Resolution 1244 (1999) Adopted by the Security Council at its 4011th meeting, on 10 June 1999, http://daccessdds.un.org/doc/UNDOC/GEN/ N99/172/89/PDF/N9917289.pdf?OpenElement. 
Narodów Zjednoczonych w Kosowie (UNMIK), na czele której stanał Specjalny Przedstawiciel Sekretarza Generalnego (Special Representative of the Secretary-General, SRSG) ONZ ds. Kosowa. Stosownie do treści rezolucji, cała władza ustawodawcza, wykonawcza i sądownicza w prowincji znalazła się w rękach UNMIK. Co istotne, mandat UNMIK obejmował także wspieranie procesu politycznego, prowadzącego do określenia przyszłego statusu Kosowa ${ }^{3}$.

Niemal od początku działań administracji międzynarodowej stało się jasne, że rzeczywista stabilizacja w powojennym Kosowie musi uwzględnić polityczne aspiracje tamtejszych Albańczyków. W tym celu w grudniu 1999 r. UNMIK powołała do życia Tymczasową Połączoną Strukturę Administracyjna (Joint Interim Administrative Structure, JIAS), w ramach której wszystkie siły polityczne i grupy etniczne Kosowa uzyskały formalne prawo do współrządzenia prowincją razem z UNMIK. Powołanie JIAS skutkowało włączeniem dotychczasowych albańskich przywódców politycznych w zarządzanie oraz pozwoliło na dobrowolną likwidację struktur albańskiego „państwa równoległego”, stanowiącego odpowiedź na zniesienie przez władze w Belgradzie autonomii Kosowa oraz wyrażającego niepodległościowe aspiracje kosowskich Albańczyków ${ }^{4}$.

Ograniczone kompetencje lokalnych elit politycznych w ramach JIAS nie zadowalały ludności albańskiej, która postrzegała zakończenie działań zbrojnych przeciw Jugosławii jako militarne zwycięstwo i wyzwolenie Kosowa spod władzy Serbii przez Wyzwoleńczą Armię Kosowa (UÇK), Sojusz Północnoatlantycki i Stany Zjednoczone. Albańczycy podejrzliwie

${ }^{3}$ Ibidem; A. Yannis, Kosovo under International Administration, „Survival” 2001, vol. 43, no. 2, s. 32-33.

${ }^{4}$ K. Pawłowski, System polityczny Kosowa, [w:] Systemy polityczne państw batkańskich, red. T. Bichta, M. Podolak, Lublin 2012, s. 271-274. 
odnosili się zatem do UNMIK, oczekując, iż misja ONZ będzie stopniowo przekazywać swe kompetencje lokalnym przywódcom politycznym ${ }^{5}$.

Częściowym rozwiązaniem problemu stała się reorganizacja systemu władzy w Kosowie. Decyzją UNMIK, w miejsce zlikwidowanej JIAS utworzone zostały w maju 2001 r. Tymczasowe Organy Władzy Autonomicznej (Provisional Institutions of Self-Government, PISG). W ten sposób obok UNMIK zaczęły funkcjonować kosowskie organy władzy ustawodawczej, wykonawczej i sądowej, do których zaliczono m.in. Zgromadzenie, prezydenta Kosowa, rząd i sądy ${ }^{6}$.

Zakres kompetencji UNMIK i PISG został oficjalnie rozgraniczony, zaś misja ONZ sprawowała nadzór nad działaniami PISG, posiadając prawo do uchylenia praktycznie każdej decyzji tych organów. Utworzenie PISG nie podważało nadrzędnej władzy UNMIK, wynikającej z rezolucji nr 1244. Oznaczało jednak ważną zmianę systemową, związaną z przejściem Kosowa od formy faktycznego protektoratu międzynarodowego do postaci samorządnej jednostki terytorialnej, znajdującej się pod czasową administracja ONZ. Praktyka funkcjonowania PISG w ciagu kolejnych lat pokazała, że wraz z transferem kompetencji na rzecz organów lokalnych UNMIK coraz bardziej stawała się $\mathrm{w}$ pierwszym rzędzie instytucją wspierająca i kontrolująca kosowskie struktury władzy w realizacji powierzonych im zadań7.

${ }^{5}$ Starting from Scratch in Kosovo: The Honeymoon is Over, (seria: „ICG Balkans Report”, no. 83), Prishtinë/Priština 1999, s. i-ii.

${ }^{6}$ K. Pawłowski, op. cit., s. 274-275.

${ }^{7}$ Ibidem. 


\section{Problem statusu Kosowa}

Wkroczenie do Kosowa sił KFOR, ustanowienie UNMIK oraz utworzenie JIAS i PISG doprowadziło wprawdzie do zakończenia walk i przywrócenia autonomii tej prowincji, nie rozstrzygało jednak jej statusu, a więc kwestii, która była główną przyczyną. Ta swoista i przeciagająca się tymczasowość nie zadowalała żadnej ze stron. Podczas gdy Serbowie postrzegali obecność w Kosowie międzynarodowych sił cywilnych i wojskowych jako wroga okupację ich terytorium oraz kolejny już akt dramatu narodu serbskiego, zdecydowana większość kosowskich Albańczyków uznawała administrację UNMIK za wymuszony, ale konieczny etap na drodze do oczekiwanej pełnej niepodległości Kosowa. Odsuwanie decyzji w sprawie jego statusu na bliżej nieokreśloną przyszłość było więc dla nich daleko niesatysfakcjonujące ${ }^{8}$. Rodziło także inne konsekwencje, stawiało bowiem pod znakiem zapytania powodzenie pokonfliktowej budowy pokoju, prowadzonej przez społeczność międzynarodową w sytuacji, gdy istniejące status quo w naturalny sposób zmierzało do kontynuacji konfliktu serbsko-albańskiego o terytorium Kosowa. Mimo obecności UNMIK i KFOR, dochodziło do powtarzajacych się zamachów na życie i mienie pozostałej w Kosowie ludności niealbańskiej, która była praktycznie przez cały czas ochraniana przez KFOR. W sytuacji wzajemnej nienawiści oraz niemal całkowitej segregacji etnicznej, deklarowana przez społeczność międzynarodową koncepcja wieloetnicznego Kosowa była od początku skazana na niepowodzenie. Odnosząc

${ }^{8}$ J. Rupnik, The Postwar Balkans and the Kosovo Question, [w:] D.H. Allin [et al.], What Status for Kosovo?, ed. by D. Triantaphyllou, (seria: „Chaillot Paper”, no. 50), Paris 2001, s. 82-84; V. Surroi, Ten Concepts That Will Define the Future of Kosovo (A Personal Note), „Southeast European and Black Sea Studies” 2002, vol. 2, no. 1, s. 191-197. 
się do rzeczywistości w Kosowie po zakończeniu operacji powietrznej NATO, Fatos Lubonja stwierdził, iż Albańczycy $i$ Serbowie sq zmuszeni do wspólnego życia w momencie, kiedy nienawidza się wzajemnie bardziej niż kiedykolwiek wcześniej ${ }^{9}$.

Mimo skali międzynarodowego zaangażowania, było jasne, że przedłużająca się niepewność odnośnie do przyszłego statusu Kosowa, stanowi najważniejszy i konieczny do rozwiązania problem polityczny, który wywiera negatywny wpływ na bezpieczeństwo $\mathrm{w}$ prowincji i zagraża stabilności całego regionu Bałkanów. W efekcie coraz bardziej naglace stawało się uruchomienie procesu politycznego, który doprowadziłby do określenia ostatecznego statusu Kosowa ${ }^{10}$.

\section{Działania dyplomatyczne na rzecz rozstrzygnięcia statusu Kosowa}

Zdając sobie sprawę ze złożoności sytuacji, społeczność międzynarodowa zdecydowała się na podjęcie ograniczonych działań w kwestii statusu prowincji. W grudniu 2003 r. UNMIK i PISG przyjęły wspólnie dokument Standardy dla Kosowa, zawierający 109 szczegółowych celów,

${ }^{9}$ F. Lubonja, Reinventing Skenderbeg: Albanian Nationalism and NATO Neocolonialism, [w:] Kosovo. Contending Voices on Balkan Interventions, ed. by W.J. Buckley, Cambridge 2000, s. 106-107; M. Waldenberg, Rozbicie Jugostawii. Jugosłowiańskie lustro międzynarodowej polityki, Warszawa 2005, s. 346-348, 440-449; A Kosovo Roadmap (II). Internal Benchmarks, (seria: „ICG Balkans Report”, no. 125), Pristina-Brussels 2002, s. 17-21.

${ }^{10}$ M. Glenny, The Kosovo Question and Regional Stability, [w:] F.-L. Altmann [et al.], The Western Balkans: moving on, ed. by J. Batt, (seria: „Chaillot Paper", no. 70), Paris 2004, s. 87-97; A Kosovo Roadmap..., s. 22-23. 
wyznaczonych do realizacji przez PISG. Implementacja wskazanych celów miała doprowadzić do podniesienia kompetencji lokalnych organów władzy oraz ustanowienia w Kosowie standardów demokratycznego państwa prawa. Rada Bezpieczeństwa ONZ poparła przyjęcie dokumentu, podkreśliła konieczność implementacji wskazanych w nim standardów oraz - zachęcając PISG do rzeczywistego wdrażania standardów - zadeklarowała, że w połowie 2005 r. mogłaby zostać przeprowadzona kompleksowa ocena ich implementacji. Rada Bezpieczeństwa ONZ wskazała także, że podjęcie dalszych działań w kwestii statusu Kosowa zależeć będzie od pozytywnego wyniku tej oceny ${ }^{11}$.

Działania ONZ nie spotkały się z przychylnym odzewem ze strony mieszkańców prowincji, którzy widzieli w nich ustępstwo wobec żądań przeciwnika. Władze w Belgradzie oraz kosowscy Serbowie obawiali się, iż rzeczywistym skutkiem, pozornie neutralnej, implementacji standardów będzie odrzucana przez nich niepodległość Kosowa. Natomiast kosowscy Albańczycy uznawali konieczność wdrożenia de facto nierealistycznych standardów za celowe odwlekanie przez społeczność międzynarodową decyzji w sprawie statusu prowincji ${ }^{12}$.

${ }^{11}$ A. Balcer, M. Kaczmarski, W. Stanisławski, Kosowo - przed ostatecznym rozwiazaniem. Proces uregulowania statusu międzynarodowego - uwarunkowania historyczne i polityczne, perspektywy rozwoju sytuacji, (seria: „Prace OSW”, nr 27), Warszawa 2008, s. 19-20; S/2004/71, 26 January 2004. Report of the Secretary-General on the United Nations Interim Administration Mission in Kosovo, s. 1-2. Cytowane w artykule raporty sekretarza generalnego ONZ dostępne są na stronie internetowej UNMIK: http:// www.unmikonline.org.

${ }^{12} \mathrm{~S} / 2004 / 348,30$ April 2004. Report of the Secretary-General on the United Nations Interim Administration Mission in Kosovo, s. 1-5; S/2004/613, 30 July 2004. Report of the Secretary-General on the United Nations Interim Administration Mission in Kosovo, s. 1-4. 
Niezadowolenie albańskiej większości znalazło odbicie w wydarzeniach z marca $2004 \mathrm{r}$., kiedy to w wyniku kampanii przemocy, skierowanej przeciw kosowskim Serbom i zorganizowanej przez albańskich ekstremistów (przy niemal biernej postawie albańskich elit politycznych i PISG), zginęło 19 osób, prawie 900 odniosło ranny, a około 4,5 tys. Serbów zostało zmuszonych do opuszczenia swoich domów w południowym i środkowym Kosowie. O skali tych wydarzeń świadczy fakt, iż w wyniku zajść uszkodzeniu lub zniszczeniu uległo ponad 700 domów, należących do przedstawicieli mniejszości etnicznych, oraz kilkadziesiąt obiektów kultu religijnego Cerkwi prawosławnej. Powyższa kampania przemocy niosła ze sobą milczące, ale wyraźne przesłanie polityczne, skierowane do ONZ i całej społeczności międzynarodowej, wyrażające narastający sprzeciw kosowskich Albańczyków wobec przeciagającego się braku decyzji w sprawie przyszłości Kosowa ${ }^{13}$.

W maju 2005 r. Rada Bezpieczeństwa ONZ - informowana na bieżąco przez SRSG o implementacji standardów przez PISG - uznała, iż nastapił progres w zakresie ich wdrażania i podjęła decyzję o przeprowadzeniu kompleksowej oceny implementacji standardów. Autor sporządzonego w tym celu raportu, ambasador Kai Eide, potwierdził postępująca implementację standardów, choć w niektórych obszarach uznał ów postęp za niewystarczający. Stwierdził jednak, że wprowadzenie $\mathrm{w}$ życie wyznaczonych standardów nie jest możliwe bez uregulowania kwestii statusu Kosowa i zalecił Radzie Bezpieczeństwa ONZ rozpoczęcie dyskusji nad ostatecznym

${ }^{13}$ Collapse in Kosovo, (seria: „ICG Europe Report”, no. 155), Pristina-Belgrade-Brussels 2004, s. 10-19; J. Mertus, "Peacekeeping" in Kosovo: Mission Impossible?, [w:] Kosovo. Contending Voices..., s. 439-440; J. Batt, The Question of Serbia, (seria: „Chaillot Paper”, no. 81), Paris 2005, s. 37-39. 
statusem prowincji. Po zapoznaniu się z powyższym raportem Rada Bezpieczeństwa ONZ wyraziła zgodę na rozpoczęcie pod auspicjami ONZ bezpośrednich negocjacji między Belgradem i Prisztina, które miały doprowadzić do uregulowania statusu Kosowa. Jednocześnie Rada Bezpieczeństwa ONZ wyznaczyła granice przyszłego kompromisu, ponieważ poinformowała oficjalnie sekretarza generalnego ONZ, że popiera wytyczne, dotyczące przyszłości prowincji, zawarte w dokumencie pt. Zasady Ramowe Grupy Kontaktowej dla rozstrzygnięcia statusu Kosowa ${ }^{14}$.

Dokument, opracowany przez Grupę Kontaktową - w skład której wchodziły Stany Zjednoczone, Wielka Brytania, Francja, Niemcy, Włochy i Rosja - wzywał strony sporu do konstruktywnego zaangażowania $\mathrm{w}$ proces negocjacji oraz wyrzeczenia się wszelkich rozwiąań siłowych. Stwierdzał również, że decyzja, dotyczaca przyszłego statusu Kosowa, powinna zostać zatwierdzona przez Radę Bezpieczeństwa ONZ. Grupa Kontaktowa wyznaczyła także 10 szczegółowych zasad, które miały posłużyć do wypracowania porozumienia w kwestii statusu Kosowa. W swej zasadniczej części sprowadzały się one do stwierdzenia, że przyszłe rozwiąanie powinno wykluczyć: powrót Kosowa pod bezpośrednią władzę Serbii; działania jednostronne; użycie zbrojnej siły oraz zmiany terytorialne, np. podział Kosowa lub integrację Kosowa z innym państwem lub częścią drugiego państwa. W tej sytuacji rzeczywistym przedmiotem negocjacji mogły być tylko dwa scenariusze, a więc pełna niepodległość Kosowa, czasowo nadzorowana przez międzynarodowe

${ }^{14}$ A. Balcer, M. Kaczmarski, W. Stanisławski, op. cit., s. 20; S/2006/45, 25 January 2006. Report of the Secretary-General on the United Nations Interim Administration Mission in Kosovo, s. 1-8; Letter dated 10 November 2005 from the President of the Security Council addressed to the Secretary-General, http://www.securitycouncilreport.org/atf/cf/\{65BFCF9B-6D27-4E9C-8CD3-CF6E4FF96FF9\}/Kos S2005 709.pdf. 
struktury cywilne i wojskowe, oraz szeroka autonomia Kosowa w ramach Serbii ${ }^{15}$.

Bezpośrednie rozmowy między Serbią i PISG rozpoczęły się w lutym 2006 r. Mimo mediacji Marttiego Ahtisaariego, powołanego na stanowisko Specjalnego Wysłannika Sekretarza Generalnego ONZ ds. Przyszłego Statusu Kosowa (Special Envoy of the Secretary-General of the United Nations for the Future Status Process for Kosovo), znalezienie wspólnie akceptowanego rozwiązania okazało się niemożliwe, ponieważ władze w Prisztinie domagały się pełnej niepodległości, a Serbia godziła się jedynie na przyznanie Kosowu szerokiej autonomii ${ }^{16}$.

W lutym 2007 r. M. Ahtisaari przedłożył PISG i Republice Serbii projekt Kompleksowej propozycji na rzecz rozstrzygnięcia statusu Kosowa. Ten tzw. plan Ahtisaariego zakładał zakończenie misji UNMIK i przekazanie jej kompetencji na rzecz organów Kosowa. Zawierał także szereg szczegółowych przepisów, gwarantujących m.in. prawa mniejszości i decentralizację Kosowa. Nad implementacją planu przez kosowskie instytucje miała czuwać społeczność międzynarodowa, reprezentowana przez Międzynarodowego Przedstawiciela Cywilnego (International Civilian Representative, ICR), który miał być jednocześnie Specjalnym Przedstawicielem Unii Europejskiej (European Union Special Representative, EUSR), oraz międzynarodowe siły wojskowe pod dowództwem $\mathrm{NATO}^{17}$.

W planie Ahtisaariego nie został wprawdzie zawarty zapis o niepodległości czy też suwerenności prowincji, ale wiele

15 J. Batt, op. cit., s. 33-53; Letter dated 10 November 2005...

${ }^{16}$ J. Batt, op. cit., s. 21-32; S/2006/707, 1 September 2006. Report of the Secretary-General on the United Nations Interim Administration Mission in Kosovo, s. 7.

${ }^{17}$ Comprehensive Proposal for the Kosovo Status Settlement, March 2007, http://www.unosek.org/docref/Comprehensive_proposal-english.pdf. 
przyjętych w nim rozwiązań jednoznacznie wskazywało, że zakłada on niepodległość Kosowa, która miała być w pierwszym okresie nadzorowana przez społeczność międzynarodowa. Trudno się zatem dziwić, że plan ten spotkał się ze zdecydowanym sprzeciwem kosowskich Serbów i władz w Belgradzie. Także PISG były początkowo sceptyczne wobec tego planu, postrzegając go jako rozwiązanie odciagajace $\mathrm{w}$ czasie pełną niepodległość Kosowa. Zdając sobie jednak sprawę, że przychylne wobec żądań kosowskich Albańczyków państwa Zachodu domagaja się poparcia Kompleksowej propozycji przez PISG, Zgromadzenie Kosowa przyjęło w kwietniu 2007 r. deklarację, w której zawarło wolę pełnej implementacji planu Ahtisaariego. Z kolei radykalne środowiska albańskie otwarcie odrzuciły Kompleksowa propozycję, domagajac się bezwarunkowej niepodległości i sprzeciwiając się każdej kolejnej formie międzynarodowej obecności w Kosowie ${ }^{18}$.

Plan Specjalnego Wysłannika stał się przedmiotem dalszych serbsko-albańskich negocjacji. Mimo iż Ahtisaari starał się przekonać Serbię i PISG do obustronnej akceptacji Kompleksowej propozycji, podejmowane przez niego działania zakończyły się niepowodzeniem. W marcu 2007 r. Ahtisaari przedstawił sekretarzowi generalnemu ONZ oficjalny raport, w którym stwierdził, że wynegocjowanie rozwiązania, popieranego równocześnie przez Belgrad i Prisztinę, nie jest możliwe, zaś przedłużający się brak decyzji odnośnie do statusu Kosowa prowadzi do kontynuacji konfliktu etnicznego i zagraża bezpieczeństwu w regionie. Specjalny

${ }^{18}$ Breaking the Kosovo Stalemate: Europe's Responsibility, (seria: „Europe Report”, no. 185), Pristina-Belgrade-New York-Brussels 2007, s. $5-11$; S/2007/134, 9 March 2007. Report of the Secretary-General on the United Nations Interim Administration Mission in Kosovo, s. 1-3; S/2007/395, 29 June 2007. Report of the Secretary-General on the United Nations Interim Administration Mission in Kosovo, s. 2. 
Wysłannik wskazał również, że kosowscy Albańczycy jednoznacznie opowiadaja się za zakończeniem misji UNMIK i pragna, aby lokalne instytucje samodzielnie sprawowały władzę w Kosowie. Przywołując krwawe wydarzenia z lat 90. XX w. oraz uwzględniając rzeczywistość istniejacca w prowincji, stwierdził, że jedyna realnq opcja dla Kosowa pozostaje niepodległość, która $w$ poczatkowym okresie powinna być nadzorowana przez spoteczność międzynarodowa - celem właściwej implementacji założeń Kompleksowej propozycji przez instytucje Kosowa ${ }^{19}$.

Kompleksowa propozycja oraz raport Ahtisaariego zostały oficjalnie przedstawione Radzie Bezpieczeństwa ONZ. Mimo iż reprezentowane w niej państwa Zachodu naciskały na przyjęcie nowej rezolucji, która wyraziłaby poparcie dla planu Ahtisaariego i zastapiłaby rezolucję nr 1244, planom takim sprzeciwiła się Rosja. Wezwała do kontynuacji dwustronnych negocjacji i wskazała, że poprze jedynie rozwiązanie akceptowane równocześnie przez Serbię i PISG ${ }^{20}$.

Kolejna runda serbsko-albańskich negocjacji odbyła się pod auspicjami tzw. Trójki, w której skład weszli przedstawiciele Stanów Zjednoczonych, Unii Europejskiej i Rosji. W rokowaniach PISG potwierdziły akceptację dla gwarantującego niepodległość planu Ahtisaariego, zaś Serbia w dalszym ciagu sprzeciwiała się Kompleksowej propozycji, godząc się na przyznanie Kosowu szerokiej autonomii. W efekcie rozmowy zakończyły się na początku grudnia 2007 r. ponownym brakiem porozumienia w kwestii przyszłego statusu Kosowa ${ }^{21}$.

${ }^{19}$ Report of the Special Envoy of the Secretary-General on the Kosovo's future status, http://www.unosek.org/docref/report-english.pdf.

${ }^{20}$ Breaking the Kosovo..., s. 2-3; S/2007/395..., s. 1-2.

${ }^{21}$ Report of the European Union/United States/Russian Federation Troika on Kosovo, 4 December 2007, http://www.securitycouncilreport.org/atf/cf/ \{65BFCF9B-6D27-4E9C-8CD3-CF6E4FF96FF9\}/Kosovo S2007 723.pdf. 
Mimo fiaska rokowań, część społeczności międzynarodowej rozpoczęła działania mające zabezpieczyć dalszą obecność w Kosowie międzynarodowych sił cywilnych i wojskowych. W grudniu 2007 r. UE i NATO oficjalnie potwierdziły wolę dalszego zaangażowania w Kosowie. Na początku lutego 2008 r. Rada Unii Europejskiej podjęła decyzję o utworzeniu misji Unii Europejskiej w zakresie praworządności w Kosowie (European Union Rule of Law Mission in Kosovo, EULEX Kosovo) oraz ustanowiła stanowisko EUSR, stwierdzając, iż osoba powołana na stanowisko EUSR powinna pełnić jednocześnie funkcję ICR. Rada UE poparła zatem rozwiązanie, które przewidywał, odrzucony przez Serbię i zaakceptowany przez PISG, plan Ahtisaariego. Wreszcie, na dzień przed ogłoszeniem niepodległości przez Kosowo, Rada UE podjęła decyzję o rozpoczęciu misji EULEX, deklarując, że w ciagu 120 dni nastapi uruchomienie działań operacyjnych w Kosowie ${ }^{22}$.

W dniu 17 lutego 2008 r. Zgromadzenie Kosowa jednogłośnie przyjęło Deklaracje Niepodległości Kosowa. Dokument ten stwierdzał, że ogłoszenie niepodległości stanowi wyraz woli obywateli i jest całkowicie zgodne z treścią popieranego przez organy Kosowa planu Ahtisaariego. Deklaracja zawierała także oficjalne zaproszenie do rozpoczęcia przez ICR nadzoru implementacji Kompleksowej propozycji, uruchomienia w Kosowie misji EULEX oraz kontynuacji dotychczasowych

${ }^{22}$ Council Joint Action 2008/124/CFSP of 4 February 2008 on the European Union Rule of Law Mission in Kosovo, http://eur-lex.europa.eu/ LexUriServ/LexUriServ.do?uri=OJ:L:2008:042:0092:0098:EN:PDF; Council Joint Action 2008/123/CFSP of 4 February 2008 appointing a European Union Special Representative in Kosovo, http://www.eur-lex.europa.eu/ LexUriServ.do?uri=OJ:L:2008:042:0088:0091:EN:PDF; Kosovo: Council establishes an EU Rule of Law Mission, appoints an EU Special Representative, 16 February 2008, http://www.consilium.europa.eu/uedocs/cms_Data/ docs/pressdata/en/gena/98768.pdf. 
działań NATO. W ciagu kolejnych miesięcy władze Kosowa przyjęły szereg aktów legislacyjnych (konstytucja, ustawa o granicach państwowych itd.), które podkreślały sprawowanie przez nie pełnej jurysdykcji w Kosowie oraz potwierdzały państwowość Kosowa. Natomiast EULEX i KFOR - mimo formalnie szerokich kompetencji ICR, przewidzianych w planie Ahtisaariego - objęły kluczową rolę w nadzorowaniu i wspieraniu pracy organów Republiki Kosowa ${ }^{23}$.

$* * *$

Podsumowując powyższe rozważania, należy stwierdzić, że ogłoszenie niepodległości nie byłoby możliwe bez poparcia tej decyzji ze strony części społeczności międzynarodowej, zwłaszcza zaś Stanów Zjednoczonych, które otwarcie opowiadały się za suwerennością Kosowa. Jakkolwiek część państw z pewnościa poparła deklarację niepodległości z powodu własnych, partykularnych interesów (zapewne $\mathrm{z}$ tego samego powodu pozostałe kraje nie uznały państwowości Kosowa), słuszne wydaje się jednak przypuszczenie, że akceptacja suwerenności Kosowa wynikała w pierwszym rzędzie z przekonania o braku możliwości zatrzymania procesu budowy kosowskiej państwowości oraz z oczekiwań, że dokończenie tego procesu - zgodne z wolą większości mieszkańców prowincji - przyczyni się do stabilizacji regionu Bałkanów.

Wyrazem wspomnianego poparcia było z pewnością utworzenie przez państwa, opowiadające się za niepodległościa, Międzynarodowej Grupy Nadzorującej dla Kosowa (International Steering Group for Kosovo, ISG), która powołała do życia urzą ICR, nadzorujący w latach 2008-2012 proces implementacji Kompleksowej propozycji przez władze Kosowa.

${ }^{23}$ K. Pawłowski, op. cit., s. 278-282; Kosovo Declaration of Independence, http://www.assembly-kosova.org/common/docs/Dek_Pav_e.pdf. 
Proniepodległościowe podejście widoczne było także w działaniach UE. Mimo iż wielokrotnie podkreślała ona, że misja EULEX ustanowiona jest $\mathrm{w}$ granicach prawnych rezolucji $\mathrm{nr}$ 1244 i działa pod nadrzędną władzą UNMIK, podejmując decyzję o jej ustanowieniu i uruchomieniu, Rada UE faktycznie wyrażała wolę implementacji planu Ahtisaariego w sytuacji braku akceptacji tego planu przez Serbię oraz Radę Bezpieczeństwa ONZ.

$\mathrm{O}$ istnieniu takiego - nawet jeśli jedynie milczącego - poparcia świadczy także przeprowadzona przez sekretarza generalnego ONZ i akceptowana przez Radę Bezpieczeństwa ONZ rekonfiguracja międzynarodowej obecności cywilnej w Kosowie, związana z redukcją personelu i zadań UNMIK oraz przejęciem jej kompetencji w obszarze prawa, porządku i bezpieczeństwa publicznego przez EULEX. Wprawdzie, stosownie do treści formalnie nadal obowiązującej rezolucji nr 1244, UNMIK sprawuje nadrzędną władzę w Kosowie, jednak po ogłoszeniu niepodległości i wprowadzeniu do Kosowa cywilnej misji UE znaczenie UNMIK jest w praktyce marginalne. Rzeczywista władzę sprawuja instytucje Kosowa, działające przy wsparciu i pod nadzorem społeczności międzynarodowej.

Powyższe argumenty nie moga jednak przesłonić faktu, że ogłoszenie niepodległości przez Kosowo stało się przedmiotem niesłabnacych kontrowersji, dotyczących przesłanek, uwarunkowań, podstaw prawnych oraz skutków tej decyzji. Niezależnie od - subiektywnej w swej istocie - oceny zasadności proklamacji niepodległości przez Kosowo, należy dostrzec, że decyzja ta miała charakter jednostronny i była pozbawiona oficjalnej akceptacji ze strony Rady Bezpieczeństwa ONZ. Oznacza to, że w sensie formalnym była ona sprzeczna z wytycznymi sporządzonymi przez Grupę Kontaktową w 2005 r. Nie może zatem dziwić, iż Serbia i Rosja wielokrotnie 
wskazywały, że ogłoszenie niepodległości przez Kosowo jest działaniem bezprawnym. Można także dostrzec, że przedłożony stronom do negocjacji plan Ahtisaariego wyrażał poparcie najważniejszego żądania kosowskich Albańczyków. Trudno więc uznać, że jego postanowienia mogły kiedykolwiek zostać zaakceptowane przez Serbię.

Jakkolwiek społeczność międzynarodowa pozostaje podzielona w kwestii statusu Kosowa, zaś Republika Serbii uważa je za swoje terytorium, faktycznie od lutego 2008 r. Kosowo funkcjonuje jako suwerenna jednostka geopolityczna, której niepodległość uznało ponad 100 państw. Wprawdzie istnieje wiele powodów, by stwierdzić, że pozostaje „państwem niedokończonym", charakteryzującym się wyraźną słabością w zakresie zapewnienia obywatelom deklarowanych praw i wolności, jednak dla kosowskich Albańczyków istnienie ich własnego państwa oznacza długo oczekiwane wyzwolenie spod władzy Belgradu. Z kolei kosowscy Serbowie powszechnie odrzucają niepodległość Kosowa i pozostaja nieufni wobec instytucji międzynarodowych tam działających, które - ich zdaniem - wspieraja funkcjonowanie nieuznawanych przez ludność serbską organów Republiki Kosowa. Spór wokół statusu Kosowa trwa zatem dalej i powoduje, że możliwość wybuchu kolejnego konfliktu zbrojnego na Bałkanach pozostaje nadal aktualna. 